\title{
The Malthusian Alternative and Overpopulation in Avengers: Infinity $W$ ar and Avengers: Endgame
} Trine Mærsk Kragsbjerg $\square$

\section{Introduction}

We are currently experiencing a worldwide pandemic, which has brought back discussions of whether the current 7.8 billion people on Earth (Hedberg 3) is sustainable. The subject of population and possible overpopulation has been an unmentionable topic for a long time both generally but also in academics concerned with the environment and in media. In more recent years, overpopulation and population control has entered popular media as in the films Virus, The Matrix and in books such as Dan Brown's Inferno and Kass Morgan's The 100. Even Marvel has engaged with the subject with the films Avengers: Infinity $W$ ar and Avengers: Endgame, which are the films this essay will be dealing with. This article will argue that the two films Avengers: Infinity $W$ ar and Avengers: Endgame argue for upholding the status quo of the universe, as they portray an extreme form of a Malthusian way of thinking about the environmental situation as an alternative to the contemporary cornucopian theory of the ultimate resource, indicating that Malthusian theory will only lead to problems and by that signalling to the audience that any change in our approach towards nature and environmental problems will only lead to disadvantages. In the following, I provide a brief overview of the term cli-fi and particularly films engaging with overpopulation, secondly a literature review of articles about population, thirdly a brief explanation of the films analysed in the article and lastly an overview of the two theories which will be used throughout the essay. Then the article moves into an analysis of the two films which focuses on the depiction of the two environmental theories presented and how these relate and form the subject of overpopulation in the films with a short conclusion at the end, summarising the findings from the analysis.

Leviathan: Interdisciplinary Journal in English (ISSN: 2446-3981), No. 7, 2021.

(C) The Journal Editors 


\section{Cli-fi and overpopulation in media}

Cli-fi is a term which was coined by activist and blogger journalist Dan Bloom in 2007 and has taken on many different meanings since then, but something which is generally agreed upon is that it is about climate and science fiction. Most often the works carry some political message, varying in the impact of this (Leyda 14), and take place in the present or a near future (12), often being disaster films. Cli-fi is still a relatively new definition and as scholarly studies take time to produce, the range of articles contemplating the designation is limited. However, there is an informative article on the subject of clifi written by Michael Svoboda, in which he focuses on films. He discusses the variety of cli-fi films we have seen since 1984, separating films into seven categories based on the climate impact they depict (Svoboda 44).

Films with overpopulation often end up in the section of Antagonists in Michael Svoboda's table of films and their climate impact (45). The films in this group have a villainous something or someone who wants to harm Earth or humanity (51), the latter most often being the case when we are dealing with overpopulation in cli-fi films. An environmentalist trying to save the natural world from the human-made threats to it goes about it in an unethical way. Sometimes he decides to kill half of the human population to lessen the burden of humans on the earth by handing out free smart phone SIM cards that transmit a signal which increases aggressiveness, as the villain in Kingsman: The Secret Service does (Moore 82), other times the way to saving the natural world takes other directions, but common for many villains in these types of cli-fi films are that they consider humans 'to be like viruses' (Gellel 101).

Environmental scholars had been hesitant to discuss overpopulation in the past but have been making amends in recent years. Some have discussed the moral and ethical aspects of it (Rieder 2016; Hedberg 2020) and how it effects all life forms. Some scholars have included Malthusian theory in their discussion of the matter (Marouby 2018; Robin 2013) while others have concentrated on the theory and its counterpart, the cornucopian thinking of Julian Simon's Ultimate Resource idea (Swaney 1991; Sabin 2013) and how these have created disagreements in the field. Several have commented on the controversy surrounding the idea of overpopulation and how it is connected to the Anthropocene (Clark 2015; Buell 2016). For some scholars it is not a question of what Earth's carrying capacity is, but as Michael Harvey identifies it; '...the question that really matters is how the world's resources are managed.' (19).

The two films Avengers: Infinity $W$ ar and Avengers: Endgame conclude the Avengers franchise, which is about The Avengers, a group of superheroes who protect Earth from evil. The true villain, 
Thanos, is revealed to have been controlling everything in an attempt to fulfil his perceived destiny of bringing balance to the universe through his Malthusian-informed method of killing half of all life forms in the universe as he thinks that it is overpopulation which has tipped the ecological scales. It is Thanos' way of making amends for his own planet Titan, which he did not manage to save from this fate. Thanos manages to fulfil his destiny in Avengers: Infinity $W$ ar but the world is returned to its original form by the Avengers, his cornucopian thinking counterpart in Avengers: Endgame through humans being innovative and creating time-travel. Henceforth, the two films will also be referred to as Infinity War and Endgame.

\section{Population theories}

The theories of population growth presented by Thanos and The Avengers are nothing new. Malthusian theory has its origin in the beginning of the nineteenth century, where a professor of political economy, Thomas Robert Malthus, spoke out about the dangers of overpopulation (Robertson 4). The main idea of Malthusian theory is as that, as wrote, '...the power of population is indefinitely greater than the power in the earth to produce subsistence for man.' (Malthus 20). Malthus thought that the human population was growing at a rate which was not sustainable in the long run and that random checks in form of famine, war and epidemics would correct this imbalance (Linnér 27). The contemporary form of Malthusian theory which Thanos and most environmentalists engage with is based on the writings of the biologist Paul Ehrlich, who also identifies unplanned regulations on the population in our time and believes that all environmental problems can be traced back to overpopulation, which our human sexual drive is partly to blame for (Robertson 136, 141, 143). Returning the theory to its origin, as Malthus' ideas inspired Darwin and his contemporaries' ideas of natural selection (5), Paul Ehrlich draws on the idea from the Darwinian Synthesis that humans are not above nature but part of it in his version of Malthusian theory (146). When it comes to the matter of coercion and population control, the contemporary form of Malthusian theory formulated by Ehrlich is unclear, neither renouncing it nor calling for it directly (126).

As a static counterpart to Thanos and his Malthusian ideas, The Avengers align with the ideas of the economist Julian Simon, who developed the theory of the ultimate resource, which is the human mind, in response to the Malthusian ideas of Paul Ehrlich. As Julian Simon describes; 'The ultimate constraint upon resource availability is human imagination' which means that 'population growth can augment resources in the long run by increasing knowledge.' (Simon 107). He believes that a growth in number of humans can only be a positive thing as this means more minds to think innovatively, 
resulting in better methods when it comes to farming, extracting natural resources and creation of land $(88,91)$. The theory rejects the idea of finite resources and carrying capacity and believes environmental problems can be solved by technology, which is what makes it cornucopian, and why it will be referred to as such (Arney 184). It lies within the idea of human imaginations as a resource that the theory does not suggest coercion, but believes that in reaction to market forces humanity will invent solutions to any problems that may form (Swaney 500). The theory of ultimate resource puts the human at the centre of the world, as it is the actor who must perform to improve the conditions of all beings, which leads the theory to have an anthropocentric focus built within its core.

\section{The topic of population and environmental problems in Avengers: Infinity War and Avengers: Endgame}

Avengers: Infinity $W$ ar and Avengers: Endgame only have a universal focus on the surface, which has a negative effect on Thanos' Malthusian message. Despite dialogue including sentences such as: 'This universe is finite, its resource finite.' (emphasis added) in Infinity War and 'the universe required correction.' (emphasis added) in Endgame, the films do not illustrate anything but an anthropocentric view. The audience only see humans, humanlike aliens or anthropomorphised animals throughout the two films, and they are all trying to save Earth. Other species' planets are not interesting, as the films only once refer to them by relating those planets having the same problems as Earth, continuing the anthropocentric view. The anthropocentric focus is not very surprising because 'The Population Reduction Argument is an anthropocentric one - it focuses only on the interests, needs, and values of human beings.' (Hedberg 10). The discussion of population reduction has yet to gain more dimensions than the one of humans, which Infinity $W$ ar and Endgame only emphasise through the constant and exclusive portrayal of humans' lives and struggles. A narrative which alerts to a more universal focus when it is not the case, is problematic as it weakens the argumentative case of the Malthusian beliefs which Thanos is trying to promote. His theory is not shown to affect any other species but humans, which diminishes his case as there is no proof that it is the entire universe he is correcting and furthermore, the audience does not engage with his theory more than in terms of how it affects the human world.

The films construct Thanos' ideology as the reason why he perceives himself as a god and above the natural world. Thanos is told early in the first film, Infinity $W$ ar, that he will never be a god, and later he speaks of finally resting when he has completed his destiny, like the Christians' God did after 
creating the world. In Endgame, we are shown idyllic long shots showing green nature and a small cottage surrounded by crops, while the sounds of birds and a low buzzing play over the almost pictural frames of a harmonious world, where Thanos is residing after completing his destiny, an image which tends towards the pastoral. All of this combines to portray Thanos as a character who perceives himself as godlike, because he finds satisfaction in doing a Malthusian check on the population of the universe by cutting it in half by random instead of waiting and 'relying on unplanned population controls' (Malthus 27). This connection between Malthusian ideas and anthropocentrism falsely represents the theory. Thanos does act as if he is above nature, but this cannot truthfully be based on Malthusian theory, which views all beings as part of the natural world and not above it. Through this misrepresentation of Malthusianism, the audience is falsely led to believe that it is those beliefs which make Thanos look down on nature and control humans' lives.

However, the films fail to recognise that the cornucopian beliefs of The Avengers are anthropocentric which weakens their case against the alternative environmental theory. The ideology of the human imagination being the ultimate resource is based on the idea of human intervention in natural processes. In Endgame, The Avengers manipulate time and intervene in the progression of life, and it is not the only instance wherein The Avengers, the representatives for humanity in the films, have done so. One of the Avengers has through radiation transformed his being, another has a reactor in his chest and a third is superhuman after being transformed by injections. Whenever there is a problem whose solution would further humanity's own position, humanity will inevitably develop solutions to the problem or as the inventor of the ultimate resource theory, Julian Simon, writes about coal: 'Because of the perceived future need for coal, and because of the potential profit in meeting that need, prospectors searched out new deposits of coal, inventors developed better ways to get coal out of the earth, and transportation men developed cheaper ways to move the coal' (88). This applies to all problems that humanity encounters where there is a profit to gain. In the real world, humans have invented ways of prolonging and improving human lives through manipulating nature in form of medicine, surgery and radiation, when a need for improvements within these fields arose. The cornucopian ideas which inform The Avengers' actions are anthropocentric in their origin and this is noticeable in the films, which blur the line between the good guys' theory and the bad guy's theory. The films argue against themselves by having depicted the anthropocentric view of Thanos' Malthusian ideology as bad, yet such views are encompassed in their heroes' ideology.

Thanos is portrayed as a three-dimensional character in the films through the narrative of a hero's journey given to him in Infinity War. Thanos repeats throughout both films what the goal of his 
mission is, but in one scene in Infinity $W$ ar, he describes the idea explicitly when he says: 'Too many mouths, not enough to go around.'. This scene is set on his home planet, Titan, which fell to devastation, according to Thanos, because of the problem quoted above. Thanos stands in the centre of the shot as the audience is shown the idyllic past of the planet before being returned to the devastated current state of it and Thanos standing there, the lone survivor of the fall of his home. The mise-en-scène makes the audience feel sympathy for him, making them perceive him as a misguided individual. A villain with a detailed backstory, who believes he is doing the right thing. The audience is given a reason behind Thanos' actions and throughout Infinity $W$ ar they follow him as he goes on a hero's journey to fulfil his destiny of saving the universe, a well-known narrative found in fictional works, and accomplishes it. Throughout Infinity War it is established that he is more than just a villain for The Avengers to fight. He cries as he must sacrifice the only thing he loves, which is his daughter, and he is shown to be exhausted after the snap cost him 'everything'. The hero's journey narrative illustrates Thanos as more than just a flat villainous character, but a complex one with more sides to explore.

Although Thanos is portrayed as a complex character, the films undermine the positive aspects of the Malthusian theory by making the problem with the ecological balance be a simplistic idea of overpopulation. Thanos finds that the universe is not balanced as it should be because of overpopulation. The Avengers do not see any problem as their cornucopian theory is based on human intelligence and more humans are only more minds to think, disregarding the idea. The portrayal of overpopulation in the films wrongfully reduces Malthusian theory to being one-dimensional. Although the theory has the relation between population growth and resources as its main focus, it does deal with other aspects of overpopulation such as environmental deterioration due to other ecological factors originating from overpopulation (Robertson 142). The theory has also improved the situation of the world through sex education, birth control and abortion rights (126). The idea of overpopulation is not a simple concept which Malthusian theory certainly illustrates by its diverse handling of it. Furthermore, the problem with the ecological balance is not just overpopulation. It is also how the world population acts (Swaney 505), the carrying capacity of the earth (Rieder 3), and various other aspects. The idea of overpopulation and possible other environmental problems are undermined by the cornucopian theory which informs the heroes in the films as it is built upon the idea that any problem will be solved by the human innovativeness, which means there is never truly a problem to worry about. This leads to the portrayal of Malthusian ideas, which acknowledge such environmental problems, as superficial and unwarranted. 
The films neutralize the controversial subject of overpopulation by making it the agenda of the villain. An audience will easily rally behind the old-fashioned narrative of superheroes vs super-villain, as reflected in the first confrontation between Thanos and The Avengers in Endgame. In this scene, Thanos acts according to his beliefs that, as a Malthusian report in the Australian Census of 1911 puts it: '[w]ithin periods of time, insignificant compared with geologic ages, the multiplying force of living things, man included, must receive a tremendous check' (qtd. in Knibbs 35), but as the narrative havs constructed him as a villain, it is implicit that whatever he wants to do must be bad. After all, 'the genre is the message' and these films are disaster films with an antagonist as their climate impact as categorised by Michael Svoboda $(56,51)$. The idea of overpopulation expressed by Thanos is immediately marked as simply villainous. As he is not one of the characters the audience is rooting for, and as those characters do not give the impression of overpopulation being a problem, the subject must simply be an idea invented by the villain. The films give a simple solution to a complex problem, as they make overpopulation uncontroversial by reducing it to be part of the familiar plot structure of an evil scheme by a villain who needs to be defeated.

The return to status quo at the end of Endgame undermines Thanos' Malthusian idea of environmental problems. By returning the world to its previous condition, The Avengers eliminate Thanos and his mission from the equation. Thanos warns that he is inevitable, meaning that overpopulation and checks to regulate this phenomenon will happen no matter what, but by the end of Endgame nothing has changed. The universe is continuing on as it did before he arrived. The continuity of status quo reduces Thanos' Malthusianism to what is the best-known version of it, that ' $[\mathrm{t}$ ] o be Malthusian is to cry wolf about limits, generally because one fails to estimate the human capacity to postpone those limits through ingenuity and unforeseen scientific discoveries' (Marouby 54). Thanos may be right that inevitably something will happen, but as The Avengers invent time-travelling, they postpone the limits and consequences that Thonas has in mind. By returning to an untouched world, the films do not simply undermine Thanos' Malthusian beliefs by erasing any trace of them, but represent an unlimited world, which ignores that there are always reactions to one's actions.

The narrative's return to status quo at the end of Endgame undermines not only Thanos' theory but also the cornucopian thinking of The Avengers. As Michael Svoboda writes about disaster cli-fi films; '... the habitual return to normalcy at the end of disaster films risks understating the problem, turning it into a one-time event...' (56). By returning to an untouched world, the films hinder the evolution of the theory of human resourcefulness which characterises the status quo in the fictional universe. They do this by indicating it was a 'one-time event', by making the audience watch the world 
situation return back to where we started. To activate the ultimate resource of human imagination there must be a demand for it, as 'people become creative primarily in response to market forces' (Swaney 500). Without the need for innovation, the process of inventiveness will not take place. Following the line of thinking represented by the cornucopian theory, there must not be a problem that needs a solution if the process of creativity does not take place. It turns into a vicious circle originating from the sense of closure from the happy ending of Endgame, which leads it to undermine not only the theory it opposes but also its own ideas.

By building Thanos' ideology on notions of coercive action from the real world, the films use the unclear formulation of contemporary Malthusianism on the matter of coercion to further discourage the audience from trying to understand the motivations behind alternative environmental views. As ' $[a]$ ttempts to limit human population increase during the past half century' have been ruined in the real world by cases of coercion such as 'forced abortion and sterilization in India and China of the 1970s...' (Buell 24), in the films, Malthusian theory is connected with population control and force. Thanos cuts the population of the universe in half without discussing it with anybody else, expressing coercive tendencies which the audience view as 'morally unacceptable' (Hedberg 5). The American audience, who will encounter the films first as they are American in origin, also have lingering bias in favour of large families' (Buell 24), which would make them react in an extreme manner to the idea of resizing the families which would happen if the population was minimised. This portrayal of an alternative environmental strategy undermines the contemplation of environmental alternatives to current measures by making strong connections between Thanos' Malthusianism and the misguided use of Malthusian theory in coercive ways in the real world.

The last film, Avengers: Endgame, does illustrate a little of the positive outcome from the application of Malthusian theory by Thanos, but this is undermined by the anthropocentric focus of the other characters in the film. Early in the film it is mentioned that one of the characters have seen a pod of whales in the Hudson river, a direct result of 'Thanos' removing half of all humans, which led to fewer ships and fewer ships means cleaner water. It's a point of view which is not found anywhere else in the films. The Avengers have a very narrow anthropocentric focus. They care about humanity and nothing more, as seen by the answer to the observation of whales: 'You know, if you're about to tell me to look on the bright side...' The narrative is focused on the effect the snap had on humans and a dialogue about other life forms is immediately turned to focus on humanity. The scene has dark lighting, and a character has tears in her eyes, as her hope for a solution is fading. The audience is pushed by the mise-en-scène to have an anthropocentric focus, to focus on the suffering of the human 
character and feel sympathy for her. The comment about the whales is not made to make the audience think about the possible positive outcomes of Malthusian ideology but to further the anthropocentric agenda of the films. Through this scene, but especially through the lack of scenes commenting on the beneficial sides of Malthusian theory and the films' anthropocentric focus, the audience misses out on contemplating different ways to view the situation.

\section{Conclusion}

In conclusion, the two films Avengers: Infinity $W$ ar and Avengers: Endgame support the continuing of current status of the universe, by relating the negative aspects of Malthusian theory to the audience and painting positive or neutral aspects in a negative light, while praising the cornucopian beliefs of the ultimate resource through narrative techniques and associations to reality. While the films at times fail to cover their bases and let negative aspects of the status quo theory come to light together with positive aspects of the alternative, it argues for the upholding of the current view on environmental issues by making the presented environmental alternative, and by association all other environmental alternatives, seem disadvantageous or simply outright unwarranted. 


\section{Works cited}

Arney, Jo. 'Cornucopians.' Green Ethics and Philosophy: An A-to-Z Guide, edited by Julie Newman, Thousand Oaks: SAGE Publications, Inc., 2011, pp.184-188. SAGE Knowledge. 14 Dec. 2020, doi: http://www.doi.org/10.4135/9781412974608.n28.

Avengers: Endgame. Directed by Anthony and Joe Russo, Marvel Studios, 2019.

Avengers: Infinity War. Directed by Anthony and Joe Russo, Marvel Studios, 2018.

Buell, Lawrence. 'Anthropocene Panic: Contemporary Ecocriticism and the Issue of Human Numbers.' Frame, no. 29, 2 Nov. 2016, pp. 11-27.

Clark, Timothy. Ecocriticism on the Edge: The Anthropocene As a Threshold Concept, Bloomsbury Publishing Plc, 2015. ProQuest Ebook Central, https:// ebookcentral-proquestcom.ez.statsbiblioteket.dk:12048/lib/asb/detail.action?docID=2056898.

Gellel, Adrian, et. al. 'Editorial.' International Journal of Children's Spirituality, vol. 24, no. 2, 2019, pp. 101-103. Taylor\&Francis Online, doi:10.1080/1364436X.2019.1629569

Harvey, Michael. 'The Anthropocene crisis: Changed mismanaged.' Utopia in the Anthropocene: A Change Plan for a Sustainable and Equitable World. 1st ed., Routledge, 2019, pp. 13-27. Taylorer Francis Group, https://doi-org.ez.statsbiblioteket.dk:12048/10.4324/9780429459054.

Hedberg, Trevor. 'The uncomfortable reality of rising numbers.' The Environmental Impact of Overpopulation: The Ethics of Procreation. 1st ed., Routledge, 2020, pp. 3-13. Taylor\& Francis Group, https://doi-org.ez.statsbiblioteket.dk:12048/10.4324/9781351037020.

Knibbs, George. 'The Shadow of the World's Future.' Robin, The Future of Nature, pp. 31-36.

Leyda, Julia. 'The Cultural affordances of Cli-Fi'. The Dystopian Impulse in Contemporary Cli-FI: Lessons and Questions from a Joint Workshop of the LASS and the JFKI (FU Berlin), pp. 11-17.

Linnér, Björn-Ola. 'Commentary: Thomas R. Malthus, An Essay on the Principle of Population (1798).' Robin, The Future of Nature, pp. 27-30.

Malthus, Thomas. 'An Essay on the Principle of Population.' Robin, The Future of Nature, pp. 19-26. Marouby, Christian. 'The Malthusian moment.' The Question of Limits: A Historical Perspective on the Environmental Crisis. 1st ed., Routledge, 2018, pp. 48-69. Taylor\&Francis Group, https://doiorg.ez.statsbiblioteket.dk:12048/10.4324/9780429444166.

Moore, Ellen E. 'The Spy Who Saved Me: Sustainability, Identity, and Intrigue in the Espionage Thriller.' Landscape and the Environment in Hollywood Film, Palgrave Millan, Cham, 2017, pp. 6795. Palgrave Studies in Media and Environmental Communication. SpringerLink, https://doiorg.ez.statsbiblioteket.dk:12048/10.1007/978-3-319-56411-1_3. 
Rieder, Travis N. 'Global Population and Public Health.' Toward a Small Family Ethic: How Overpopulation and Climate Change Are Affecting the Morality of Procreation, Springer, Cham, 2016, pp. 1-12. SpringerBriefs in Public Health. SpringerLink, https://doiorg.ez.statsbiblioteket.dk:12048/10.1007/978-3-319-33871-2_1.

Robertson, Thomas. 'From Rubbish to Riots.' Introduction. The Malthusian Moment : Global Population Growth and the Birth of American Environmentalism, Rutgers University Press, 2012, pp. 1-12. ProQuest Ebook Central, https://ebookcentral-proquestcom.ez.statsbiblioteket.dk:12048/lib/asb/detail.action?docID=999509.

Robertson, Thomas. 'Paul Ehrlich, the 1960s, and the Population Bomb.' The Malthusian Moment: Global Population Growth and the Birth of American Environmentalism, Rutgers University Press, 2012, pp. 126-151. ProQuest Ebook Central, https:/ / ebookcentral-proquestcom.ez.statsbiblioteket.dk:12048/lib/asb/detail.action?docID=999509.

Robin, Libby, editor. The Future of Nature: Documents of Global Change, Yale University Press, 2013. ProQuest Ebook Central, https:/ / ebookcentral-proquestcom.ez.statsbiblioteket.dk:12048/lib/asb/detail.action?docID=3421303.

Sabin, Paul. The Bet: Paul Ehrlich, Julian Simon, and Our Gamble over Earth's Future, Yale University Press, 2013. ProQuest Ebook Central, https:// ebookcentral-proquestcom.ez.statsbiblioteket.dk:12048/lib/asb/detail.action?docID=3421270.

Simon, Julian Lincoln. " Chapter 5: Natural Resources, Pollution, and Population Growth in MDC's". The Economics of Population Growth, Princeton: Princeton University Press, 2019, pp. 82107. https://doi-org.ez.statsbiblioteket.dk:12048/10.1515/9780691197654-012.

Svoboda, Michael. 'Cli-fi on the screen(s): patterns in the representations of climate change in fictional films.' WIREs Clim Change, Vol. 7, 2016, pp 43-64. Wiley Online Library, https:/ / doiorg.ez.statsbiblioteket.dk:12048/10.1002/wcc.381.

Swaney, James. "Julian Simon Versus the Ehrlichs: An Institutionalist Perspective.” Journal of Economic Issues, vol. 25, no. 2, Routledge, June 1991, pp. 499-509. JSTOR, www.jstor.org/stable/4226431. 